\title{
The Relation Analysis of Equity Structure and Its Performance on Chinese Listed Bank
}

\author{
Chang-jun Zheng ${ }^{1}$, Zhou Yan ${ }^{2} \& \mathrm{Li} \mathrm{Wei}^{3}$ \\ School of Management of HUST, Wuhan, Hubei, P.R. China \\ Email:1'zhchjun@hust.edu.cn, ${ }^{2}$ zoeyet@163.com, ${ }^{3}$ tianyoulw@yahoo.cn
}

\begin{abstract}
With the development of reform of stock system among Chinese commercial banks, more and more listed banks are coming forth to the market, so it is important to analyze the relationship between the equity structure and its performance of Chinese listed bank. For representatives, this article selected 6 banks from the total of 14 listed banks, and then made the demonstration analysis about the relationship between the performance and equity structure, according to their different equity structures. The result shows the first major shareholder is significantly relative to banks' performance, by contract, there's no notable correlation between the big five /ten and bank's performance, but square sum of equity by the ten big is correlate to the performance.
\end{abstract}

Keywords: equity structure, performance, listed banks

\section{Introduction}

As putting up shares in domestic stock market in 1997, Shenzhen Development Bank became the first Chinese commercial bank raising money in public, and then followed by another 14 banks, such as SPD bank, Minsheng bank, Huaxia bank and so on. Since 2005, the Chinese commercial banks have sped up to issue, take three stateowned Commercial banks as the symbol, the China ICBC, the CCB and the Bank of China were all offered to the public through the issuance of shares, and this fact shows that the scale and quantity of issue has improved, and equity structure also has a big change.

Equity structure is the proportion which the shareholders have partial ownership of the corporation. Its has two meanings: the first is centralized degree which has many standard, including the sum and the square sum of equity proportion which the big five or ten shareholders has; the second is capital structure, which means the proportion of different kind of capital source, including state-owned shares, corporate shares and public shares.

As different in time and various in background of being listed bank, the data information about these 14 banks is numerous and complex. So we take 6 banks as representatives, including the Bank of China, the China ICBC, the China Merchants Bank, the Bank of Communication, the Shanghai Pudong Development Bank, and Minsheng Bank. We want to examine the results of relationship between the equity structure and performance by utilizing these six banks and offer a reference to other listed banks and listing banks.

\section{Literature Review}

Berle \& Means firstly put forward the hypothesis in their book titled Modern Corporation and Private Property, which shows the more decentralize, the worse performance is, Jensen \& Meckling considered that corporate value lie on the proportion of shares held by internal shareholder, the bigger proportion is, the higher company value is in theoretically.[1, 3]

In past 20 years, more and more scholars have studied the relationship between equity structure and performance, but they didn't come to the same conclusion. Some scholars said share centralized degree was related to performance. Grossman \& Hart's model [9] indicates that the single shareholder would lack stimulant to monitor company's management, to participate in the company's operation, or to drive company's value to grow if equity structure is too scattered, because the cost in supervision is more than return. The model developed by Shleifer \& Vishny shows the wealth brought by stock price rising causes benefit of holding shareholder and small shareholders being consistent, so some share concentration is necessary. [5]

Other scholars took the opposite view about the relationship between performance and share concentration. Pound [5] proposed conflict of interest hypothesis and strategic alignment hypothesis, which deduced the inverse correlation between share and performance. The study by Qian Sun and Wilson H.S.Tong [6] indicate state-owned shares and corporate shares make a negative effect on company's performance.

Also some scholars believed there has a curve relation between the equity structure and performance. Morck, Shleife \& Vishny studied [71] large companies list in the "Fortune", and found that it was inverted U-shaped curve 
relationship between the proportion of shareholding by company's manager and company's value. McConnell \& Servaes analyzed 1173 companies as sample in 1976 and 1093 company as sample in 1986, they discovered that the Tobin's Q is relate to shares holding by interior shareholders in curvilinear.[4,5]

Other scholars thought the performance was dependent to shares concentration. Demsets \& Lehn's research [7] found there was no significant correlation between shares concentration degrees and accountant margin. Holdmess \& Sheehan [11] concluded that there is no difference between the performance in the year existing absolutely shareholders and the year they are not existing in the same company So they considered there was no correlation between equity structure and company's performance.

$\mathrm{Xu}$ Xiaonian [12] is the first domestic scholar who used the empirical method to analyze the relationship between the company's performance and the equity structure of Chinese listed companies, he found that performance was relate to share concentration degree; the proportion of corporate shares has a remarkable positive influence to the company's performance, while the proportion of state-owned shares has a negative influence to performance, the circulation stock proportion is not remarkable to the company performance affects, but proportion of circulation stock had no significant impact on performance.

Similarly, other scholars have made empirical analysis from the perspective of kind of share. Zhou Yean [14] selected 160 samples from 745 listed companies at random at the end of 1997, inspected the relation between equity structure and net assets, and drew the conclusion: the ratio of returns on net assets were significally related to proportion of A stock, the state-owned shares and the corporate shares, but $\mathrm{B}$ stock, $\mathrm{H}$ stock had the inverse correlation relations with the ROA ratio. By observing the relation between ROA and A stock, Yu Zhidong [15] concluded that the company performance was low ralative to state-owned shares and the corporate shares, by contract, the performance was inverse correlation to A stock, the staff share and circulation stock in foreign capital, and all kinds of shareholders didn't play the due role in the company development.

Some scholars did not agree with this point of view. The study by $\mathrm{Xu}$ Xiaonian, Wang Yan [16] showed that the company's profit margins declined with increasing of proportion of state-owned shares, but increased with increasing of the proportion of corporate shares, and had no impact on public shares. Chen Xiaoyue and Xu Xiaodong [13] took empirical study in relationship between equity structure and performance among the listed companies besides financial industries in Shenzhen Stock Exchange in1996-1999 years, they deduced that in non-protection industries (including10 industries except for petroleum chemical industry, energy and raw material industry), the performance was related to scale of share holding by first major shareholder, was inverse correlate to scale of circulation stock, and no significant relation to state-owned shares or corporate shares.

Wushu Kun's [18] Empirical analysis shows that the relationship was significantly inverted U-shaped curve between performance and shares concentration degrees or internal holdings (including the staffs holding and executives manager holding), while the relationship was significantly U-shaped curve between performance and scales of circulation stock, state-owned shares and domestic corporate shares. Yang Deyong, Cao Yongxia [23] studied five listed banks on Chinese market, and found bank's performance was inversing to the biggest shareholder, and was relate to holding scale of the top five or the top 10 shareholders, and also inversing to circulation stock scales.

However, not all research shows that the equity structure and the achievements are correlative. Zhang Zongyi, Song Zengji [17] pointed out that equity structure and scales of manager's holding did not affect on the company's performance.

Getting a review of studies in equity structure and company administration in recent years, you would find following characteristic: firstly, the theory almost focus on benefit balance in shareholders and manage operators. Secondly, some scholars neglected the fact that different way of administration would make different influence on performance; also they didn't make quantitative analysis to situation and characteristic of Chinese listed companies. Thirdly, more empirical analysis, but few canonical parse analysis. Lastly, some studies neglected Chinese situation, such as "forge", effectiveness of Chinese stock market, authenticity of the stock price, and so on, and precisely was this problem leading to conflict among different studies.

\section{Methods and Tools}

\subsection{Samples}

The samples was select from annual report of six banks in the five year when is from 2003 to 2007, including the Bank of China (BOC for short), the China ICBC (i.e. ICBC), the China Merchants Bank (i.e. CMB), the Bank of Communication (i.e. BC), the Shanghai Pudong Development Bank (i.e. SPD) and the Minsheng Bank (i.e. $\mathrm{MB})$, the objects are these 6 banks, the number of samples is 30 .

\subsection{Selection and Difinition of Variables}

- Be interpreted variable $\mathrm{S}$, the composite index which measure the performance of listed banks.

\section{- Interpreted variables}

F1: Proportion of share holding by the biggest shareholders 
F5: Sum of proportion of share holding by top five shareholders

F10: Sum of proportion of share holding by top ten shareholders

HERF10: square sum of proportion of share holding by top ten shareholders, measuring the degree of shares concentration.

\section{CSP: Proportion of circulation stocks}

LSP: Proportion of corporate shares

\section{SOSP: Proportion of state-owned shares}

In this article, variable refer to the dependent variable, the independent variable and the controlled variable. The dependent variable is displayed with the performance of listed banks; the independent variable is display with CSP, LSP, SOSP and indexes such as F1, F5, F10 and HERF10. In addition, we selected ratio of debt to assets and asset size, etc., as control variables in order to control other characteristics which would make influence to performance.

\section{Qualitative Analysis and Assumptions}

\subsection{About Degree of Share Concentration}

Generally, there are 3 methods to measure equity concentration .The first is CR index, which is the sum of proportion of share holding by top $\mathrm{N}$ shareholders, and we choose F1, F5, and F10 to represent it. The second is herfindahl index, which is the square sum of proportion of share holding by top $\mathrm{N}$ shareholders, and we choose ten to instead of $\mathrm{N}$. The third is $\mathrm{Z}$ index, which is the ratio of proportion of the share holding by the biggest shareholder and the second one. The bigger the ratio, the wider the gap between the top two shareholders, which means the biggest one has remarkable predominance. In our study, we use first two indexes to measure equity concentration degree.

The larger F1, the stronger monitoring of the company, which would lead to continuing drive function and the corresponding restriction mechanism to the agent. Therefore, the bigger of first major stockholder's superiority is, the more helpful this will be in decision-making and coordination in bank it will. However, there are differences among the first major shareholders, such as their characteristics, ability of acting, which would then have a significant impact on performance of commercial banks. Only when holding shareholder is good at making correct decisions, bank performance would be improved; otherwise, it will reduce the performance. So we can make hypothesis as follows:

H1. Bank's performance is not related to proportion of share holding by first major shareholder

If shares are concentrated in some independent shareholders, not only in one shareholder, it will keep the benefits and rights in balance, which will improve on the shortcoming taken by the fact that there is only one control stockholder. However, when the proportion of these shareholders is not big enough, their own benefits may not be coherence to the banks. The bank performances should be U-shape curve relation to the equity concentration degree, and the equity concentration degree should have a best sector theoretically. So we can make hypothesis as follows:

H2. Performance of bank is related to the sum of proportion of the top five shareholders' holding, and so as to the top ten, but is U-shape curve relation to the square sum of proportion of top ten shareholders' holding.

\subsection{About Property of Shares}

In the perspective of property of shares, equity can be divided into state-owned shares, corporate shares and circulation shares. We select state-owned shares and circulation shares to measure property of shares in this article. As a major shareholder, the state is in a special status differ from other major shareholders. This is mainly because performance largely depends on the behaviors of governing by agents of the state. When proportion of the state-owned shares is low, there must be lack of effective monitoring to the bank as lacking impetus, however, if that proportion rose to a certain degree, which could make government's attention to improving in monitoring to banks, it will help to improve the performance of banks. Thus we make hypothesis as follows:

H3. The proportion of state-owned shares is related to performance in curve relation. The performance is inverse correlate to this proportion when the proportion is low, but performance is related to this proportion when the proportion is high.

Investors of circulation stocks and corporate stocks all concern about bank's performances, because they take maximum profit as the only goal. Compared to corporate stocks, investors of circulation stocks are in inferior position, but they can vote with "feet" if cannot with hands, that means they can influence the banks' performance by buying or selling stocks of banks in the stock market. So we make hypothesis as follows:

H4. Sum of proportion of the corporate shares is related to the banks' performance; and the sum of proportion of circulation stock is also related with the banks' performance.

\section{Empirical Study on Relationship between Performance and Equity Sructure}

\subsection{The Data We Collect about the Chinese Listed Banks}

We get the data from the Chinese statistical yearbooks and the Chinese finance yearbooks between 2003 and 2007, and some missing data from the listed banks' an- 
nual reports .(see the table 1).

\subsection{The Model of Equity Structure Attributing to Banks' Performance}

Theoretical analysis shows that the equity structure will

Table1.The banks' performance index and the variables. $S$ - the composite index which measure the performance of listed banks, we get it by the weighted average between PE and the net assets returns ratio; F1-Proportion of share holding by the biggest shareholders; F5 - Sum of proportion of share holding by top five shareholders; F10-Sum of proportion of share holding by top ten shareholders; HERF10 - square sum of proportion of share holding by top ten shareholders, measuring the degree of shares concentration; CSP-Proportion of circulation stocks; LSP-Proportion of corporate shares; SOSP-Proportion of state-owned shares

\begin{tabular}{|c|c|c|c|c|c|c|c|}
\hline$S$ & $\mathrm{~F} 1$ & F5 & F10 & HERF10 & CSP(\%) & LSP(\%) & SOSP(\%) \\
\hline 19.54 & 35.30 & 92.80 & 95.66 & 2709.32 & 100.00 & 0.00 & 0.00 \\
\hline 12.72 & 35.30 & 92.60 & 95.50 & 2704.13 & 100.00 & 0.00 & 0.00 \\
\hline 14.78 & 0.00 & 0.00 & 0.00 & 0.00 & 0.00 & 0.00 & 0.00 \\
\hline 9.50 & 0.00 & 0.00 & 0.00 & 0.00 & 0.00 & 0.00 & 0.00 \\
\hline 7.00 & 0.00 & 0.00 & 0.00 & 0.00 & 0.00 & 0.00 & 0.00 \\
\hline 63.21 & 17.88 & 43.23 & 51.89 & 547.46 & 100.00 & 0.00 & 0.00 \\
\hline 33.94 & 17.79 & 43.09 & 51.75 & 544.01 & 100.00 & 0.00 & 0.00 \\
\hline 26.97 & 17.78 & 37.61 & 47.06 & 454.86 & 27.00 & 63.90 & 3.70 \\
\hline 30.53 & 17.95 & 37.98 & 47.14 & 462.22 & 26.30 & 69.90 & 3.80 \\
\hline 25.61 & 17.95 & 37.98 & 47.03 & 458.68 & 26.30 & 72.00 & 1.80 \\
\hline 28.99 & 22.02 & 69.11 & 72.68 & 1289.49 & 100.00 & 0.00 & 0.00 \\
\hline 21.15 & 21.78 & 62.49 & 65.62 & 1067.13 & 50.40 & 27.90 & 21.80 \\
\hline 16.31 & 0.00 & 0.00 & 0.00 & 0.00 & 0.00 & 0.00 & 0.00 \\
\hline 2.66 & 0.00 & 0.00 & 0.00 & 0.00 & 0.00 & 0.00 & 0.00 \\
\hline 24.48 & 0.00 & 0.00 & 0.00 & 0.00 & 0.00 & 0.00 & 0.00 \\
\hline 17.62 & 67.49 & 95.32 & 97.26 & 4800.41 & 100.00 & 0.00 & 0.00 \\
\hline 13.90 & 67.49 & 95.09 & 97.07 & 4794.88 & 100.00 & 0.00 & 0.00 \\
\hline 12.40 & 0.00 & 0.00 & 0.00 & 0.00 & 0.00 & 0.00 & 0.00 \\
\hline 10.60 & 0.00 & 0.00 & 0.00 & 0.00 & 0.00 & 0.00 & 0.00 \\
\hline 14.55 & 0.00 & 0.00 & 0.00 & 0.00 & 0.00 & 0.00 & 0.00 \\
\hline 72.72 & 23.57 & 41.01 & 47.40 & 652.20 & 100.00 & 0.00 & 0.00 \\
\hline 45.29 & 23.57 & 41.37 & 47.11 & 653.43 & 100.00 & 0.00 & 0.00 \\
\hline 39.76 & 7.01 & 26.08 & 37.32 & 170.28 & 27.60 & 63.30 & 9.10 \\
\hline 31.80 & 7.01 & 26.08 & 37.06 & 168.50 & 27.70 & 62.50 & 9.80 \\
\hline 26.52 & 6.44 & 24.80 & 33.27 & 140.74 & 27.70 & 65.20 & 7.10 \\
\hline 28.19 & 5.90 & 25.57 & 44.35 & 202.45 & 100.00 & 0.00 & 0.00 \\
\hline 25.43 & 5.98 & 25.97 & 42.00 & 190.26 & 100.00 & 0.00 & 0.00 \\
\hline 27.24 & 5.99 & 25.98 & 42.06 & 190.59 & 100.00 & 0.00 & 0.00 \\
\hline 27.40 & 6.98 & 29.46 & 48.40 & 251.61 & 30.10 & 69.90 & 0.00 \\
\hline 26.21 & 7.40 & 32.61 & 53.27 & 303.54 & 26.00 & 74.00 & 0.00 \\
\hline
\end{tabular}


Table 2. the regression analysis between the banks' performance and the equity attribution

\begin{tabular}{lllllll}
\hline & Coefficients & Std. Error & t Stat & P-value & Lower 95\% & Upper 95\% \\
\hline Intercept & 12.469 & 4.37929 & 2.8473 & 0.0085 & 3.467373 & 21.4709118 \\
CSP(\%) & 0.1979 & 0.05791 & 3.4164 & 0.0021 & 0.0788103 & 0.31689295 \\
LSP(\%) & 0.1635 & 0.09333 & 1.7514 & 0.0917 & -0.028383 & 0.35528582 \\
SOSP(\%) & -0.011 & 0.58503 & -0.02 & 0.9845 & -1.214039 & 1.19104615 \\
\hline
\end{tabular}

Table 3. The regression analysis between the banks' performance and the equity attribution. A Dependent Variable: S

\begin{tabular}{|lllllll}
\hline \multirow{4}{*}{1} & model & \multicolumn{2}{l}{ Unstandardized Coefficients } & Standardized Coeffi- & t & Sig. \\
& & B & Std. Error & Beta & B & Std. Error \\
& (Constant) & 12.469 & 4.379 & & 2.847 & 0.008 \\
& CSP & 0.198 & 0.058 & 0.577 & 3.416 & 0.637 \\
& LSP & 0.163 & 0.093 & 0.327 & 1.751 & 0.984 \\
& SOSP & -0.011 & 0.585 & -0.004 & -0.020 & 0.276 \\
\hline
\end{tabular}

Table 4. The relation between the banks' performance and the proportion of CSP. Model Summary and Parameter Estimates. Dependent Variable: S; the induced variable is the banks' performance index S,the independent variable is the proportion of CSP. The independent variable is proportion of circulation stocks

\begin{tabular}{|l|l|l|l|l|l|l|l|}
\hline \multirow{2}{*}{ Equation } & \multicolumn{4}{|l|}{ Model Summary } & \multicolumn{2}{l|}{ Parameter Estimates } \\
\cline { 2 - 8 } & R Square & $\mathrm{F}$ & $\mathrm{df1}$ & $\mathrm{df2}$ & $\mathrm{Sig}$ & Constant & b1 \\
\hline Linear & .229 & 8.335 & 1 & 28 & .007 & 17.188 & .164 \\
\hline
\end{tabular}

Table 5. The relation between the banks' performance and the concentration ratio of $t$ he equity. A Dependent Variable: $\mathrm{S}$

\begin{tabular}{|l|l|l|l|l|l|l|}
\hline & model & Unstandardized Coefficients & Standardized Coefficients & $\mathrm{t}$ & Sig. \\
\hline & & B & Std. Error & Beta & B & Std. Error \\
\hline 1 & (Constant) & 12.772 & 3.299 & & 3.871 & 0.001 \\
\hline & F1 & 2.020 & 0.457 & 2.376 & 4.421 & 0.000 \\
\hline & F5 & -.182 & 0.435 & -0.370 & -0.418 & 0.680 \\
\hline & F10 & 0.294 & 0.341 & 0.621 & 0.862 & 0.397 \\
\hline & HERF10 & -0.030 & 0.006 & -2.563 & -5.31 & 0.000 \\
\hline
\end{tabular}

formance, we have done the regression analysis by using the tools Excel and SPSS based on the related data of the listed banks. The results which get from Excel are showed in table 2 .

The results which get from SPSS are showed in Table 3.

From the analysis of P-value and the coefficient of significant level (sig), we get the conclusions: The P-value and the sig about CSP is 0.02 (smaller than 0.05), which means there is a linear relation between the proportion of circulation stocks and the banks' performance; The related coefficients about LSP and SOSP are bigger than 0.05 , which means there is no linear relation between the proportion of corporate shares (the proportion of stateowned shares) and the banks' performance.

In the following we have done specific research about the linear relation between the proportion of circulation stocks and the banks' performance, assume $\mathrm{S}=b_{0}+b_{1}$ * $\mathrm{CSP}+\mathrm{e}$, we did the linear regression by SPSS, the result is showed in Table 4.

By the result we can get $S=17.188+0.164 \mathrm{CSP}+\mathrm{e}$, that means there is a positive linear relation between the banks' performance and the proportion of circulation stocks.

\subsection{The Model of the Equity Concentrative Degree's Effect to Banks’ Performance}

To test the relationship between the equity concentrative degree and banks' performance we take banks' performance as the result of the equity concentrative degree, financial leverage and the company's assets complicated action, as the corporation's data shows, the explanatory ability and the fitting degree which independent variable to dependent variable is the strongest, the relationship between them is shown below:

$$
\mathrm{S}=\mathrm{a}_{0}+\mathrm{a}_{1} \mathrm{~F}_{1}+\mathrm{a}_{2} \mathrm{~F}_{5}+\mathrm{a}_{3} \mathrm{~F}_{10}+\mathrm{a}_{4} \operatorname{HERF} 10+\mathrm{e}
$$


F1 Line Fit Plot

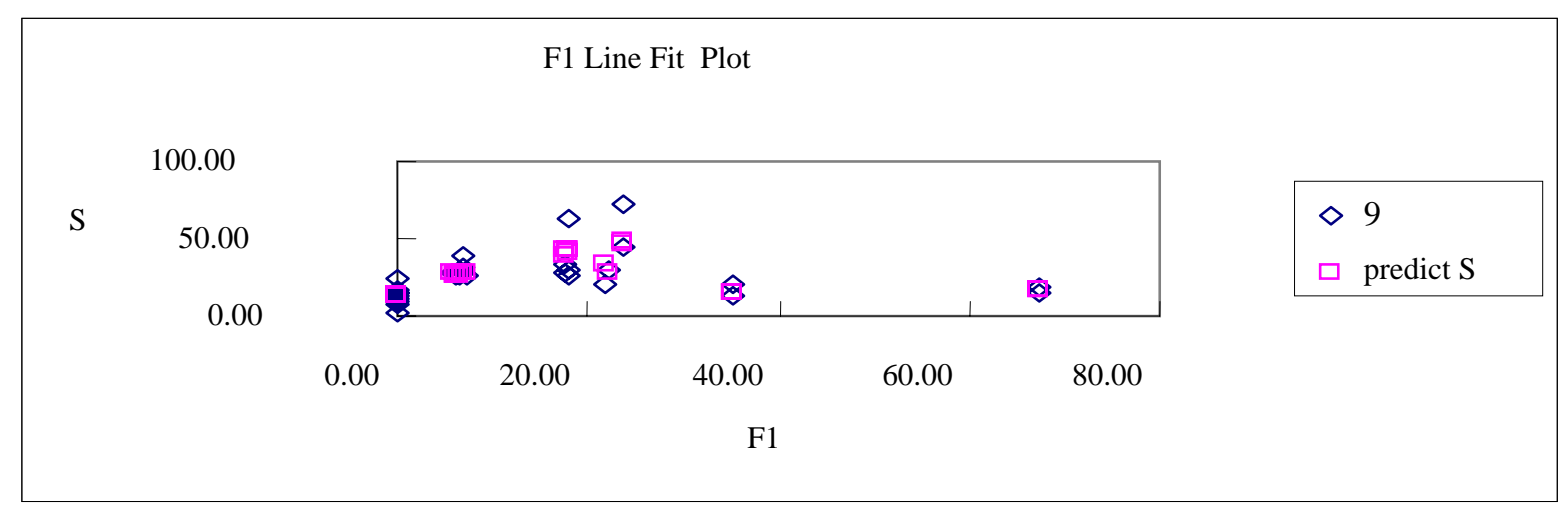

Figure 1. Fitting chart of real S and predict S used by F1

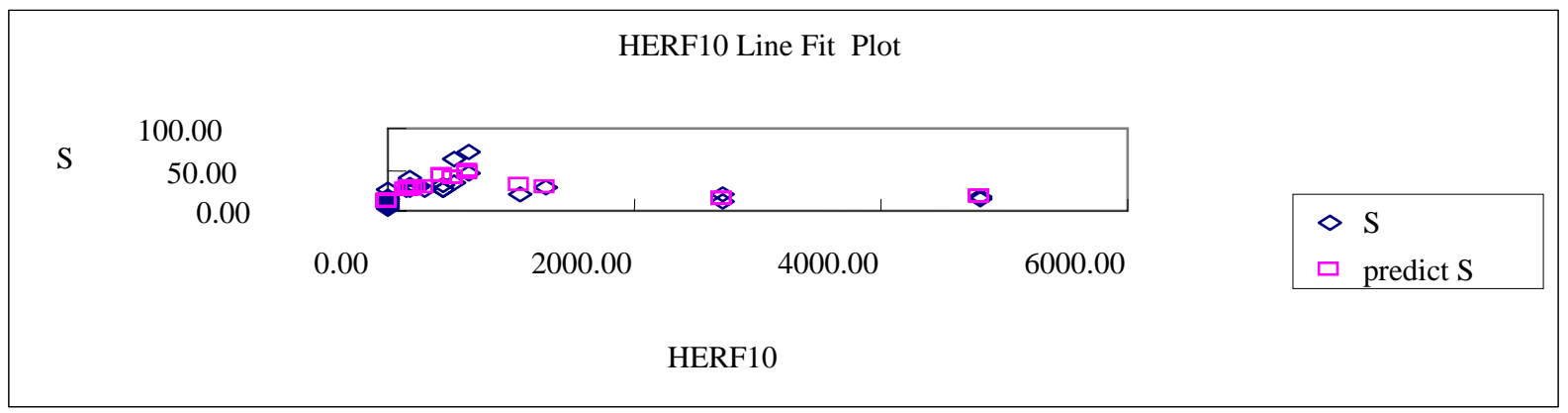

Figure 2. Fitting chart of real S and predict $S$ used by HERF10

In which the variable $S$ is the banks' performance, measured by earnings per share and net assets yield, $\mathrm{a} 0$ is a virtual variable delegates the intercept, F1 is the stock proportions that the first major shareholder holds, F5 is the stock proportions that the top five shareholders hold, F10 is the stock proportions that the top ten shareholders hold, HERF10 is the square sum of the top ten shareholders' proportions. Regression results are as follows:

The results: coefficient of significant level (sig) of proportion of shareholding by the biggest shareholders (F1) is 0.000 , far less than 0.05 , and the same to the square sum of proportion of share holding by top ten shareholders (HERF10), which explains proportion of shareholding by the biggest shareholders (F1) and the square sum of proportion of share holding by top ten shareholders (HERF10) can interpret the variables S significantly. But coefficient of significant level (sig) of Sum of proportion of share holding by top five shareholders (F5) and proportion of share holding by top ten shareholders (F10) are far more than 0.05, which means F5 and F10 is not suitable for interpreting the variables $\mathrm{S}$.

Actually, from the picture drew by SPSS, we can find the performance $(S)$ predicted by $\mathrm{F} 1$ and HERF10 is highest fitting to real performance, which means a significant interpreting to the variables $\mathrm{S}$. pictures drew by SPSS are as follows:

\section{Conclusions and Suggestions}

In summary, through the qualitative analysis and the empirical research of listed banks in China, we obtain some conclusions below:

First, choose the net asset yield and per share yield, we have constructed an Index $S$ to reflect the particularity of banks' performance. However, because it is difficult to acquire relevant data, the construction of the index is not perfect; it is just an idea of reference, to make the indicators used to measure the banks' performance more reasonable.

Second, between the proportions of the first major shareholders in commercial bank and the performance of banks there is a significant correlation. As we have described in the qualitative analysis, the largest shareholder of governance will have a direct effect on performance of the bank, and to strengthen the shareholding ratio of the top five and the top 10 shareholders, forming a certain degree of control over checks and balances will help improve the listed Banks operating performance.

Third, the "multiple checks and balances" is a better equity structure. Decentralization and lower the largest shareholder's equity proportions can avoid the major shareholder controlling the bank effectively, and improving the structure of the bank's corporate management.

Fourth, changing the constitute of the circulation share that the shareholders hold, introducing a treatment capacity of institutional investors, one hand it is helpful of introducing and making use of foreign capital, the other hand it is helpful of introducing the advanced experience of foreign country. It is better for our country to optimize the combination of capital , and to drive the fund flow to 
the shareholders more reasonable, to improve the unsuitable structure of equity, further to improve corporate governance structure of China's listed companies and also it is helpful to enhance China's listed banks operating performance.

In conclusion because the banks in China is special, and in some state-owned commercial banks, the special performance is even more obvious, the interest rate is still controlled by the government, information disclosure is not entirely, but because the stock market is a bull market in 2007, Listed bank's annual report data generally higher, so the data's reliability remains to be improved. It can be said that the relationship between shareholding structure and listed banks' performance cannot be fully reflected from data of the listed banks' e annual report, but we can get some e enlightenments from this research, as a reference for the just listed and the forthcoming listed commercial banks in China.

\section{REFERENCES}

[1] Berle \& Means, Modern, "Corporation and Private Property”, The Macmillan Company, 1944, pp.69-70.

[2] Fama, E. \&Jensen, M., "Seperation of ownership and control”, Journal of Law and Economy, Vo1.26, 1983 pp.301-325.

[3] Jensen, M.C.and Meckling, W.H."Theory of the Firm: Managerial Behavior, Agency Costs and Ownership Structure”, Journal of Financial Economics, vol.3, 1976, pp. 305-360.

[4] McConnell and Servaes, "Additional Evidence on Equity Ownership and Corporate Value", Journal of Financial Economics, Vol.27, 1990, pp.596-612.

[5] John Pound; Richard J Zeckhauser 1988: "The market for corporate control :the economics of corporate takeovers and the New Zealand takeover code : an analysis and proposals for reform " [Auckland, N.Z.] : New Zealand Centre for Independent Studies.

[6] Qian Sun and Wilson H. S. Tong, “China share issue privatization: the extent of its success", Journal of Financial Economics, Volume 70, Issue 2, Nov., 2003, pp.183-222.

[7] Demsetz and Lehn, "The Structure of Ownership : Causes and Consequences", Journal of Political Economy , Vol.93, 1985, pp.11155-11771.

[8] Morck, Shleifer and Vishny ,"Management Ownership and Market Valuation: An Empirical Analysis”, Journal of Financial Economics,Vol.20, 1988, pp.293-315.

[9] Sanford J Grossman; Oliver D Hart; Hayne E Leland 1980: "Corporate financial structure and managerial incentives,
Cambridge, Mass. : National Bureau of Economic Research,”.

[10] Thomsen, Steen, "Ownership structure and economic performance in the largest European companies" Strategic Management Journal, vol.21, no.6, 2000, pp.689-705.

[11] Holdemess, C. and Sheehan, D., "The Role of Majority Shareholders in Publicly Held Corporations", Journal of Financial Economics, 1988, pp.20.

[12] Xu Xiaonian 1997: "Building a company governance mechanism and capital market on the base of corporation structure”, reform, vol 5, 1997.

[13] Chen xiaoyue, Xu xiaodong, "equity structure, corporate performance and protection of investors' interests" Economic Research, no.11, 2001.

[14] Zhou Ye an 1999: "The empirical research on influence of financial repression to enterprise financing ability " Economic Research Journal, issue 2, 1999.

[15] Yu Zhidong 2002: “The corporate governance of listed company in a changing economic environment" publishing house of Renmin University of China, 2002.

[16] Xu Xiaonian, Wang Yan, 2000: "The Structure of Ownership and corporate governance on Chinese listed company", publishing house of Renmin University of China.

[17] Zhang zongyi, Song zengji, "Empirical Study in equity structure and corporate performance of listed companies", Quantity economical technical economy research, no.1, 2003.

[18] Wu Shu-kun 2002: "Ownership structure and firm performance: an empirical research on Chinese public companies”, China Industrial Economy, issue 1, 2002.

[19] Xu xiaodong, Chen xiaoyue, "analysis of the first major shareholders' impact on corporate governance and performance”, Economic Research, no.2, 2003.

[20] Bai chongen, etc. Empirical Study in governance structure of Chinese listed companies Economic Research, no.2, 2005.

[21] Li hanjun, Zhang junxi, 2006, “The endogenetic degree of Listed corporate governance and performance." , Management World, no.5.

[22] Xu liping, etc. "Equity Concentration \& Multi-shares Balance and impact in corporate performance”, Economic Research, no.1, 2006.

[23] Yang deyong, Cao yongxia, "Empirical Study of equity structure and performance about Chinese listed banks", Financial Research, no5, 2007.

[24] Li hanjun, Zhang junxi, "The endogenetic degree of Listed corporate governance and performance.” , Management World, no5, 2006. 